\title{
A CALÇADA COMO EXPERIÊNCIA DE ARTE URBANA \\ PROJETO NESSA RUA TEM UM RIO
}

Fabiana Abaurre ${ }^{1}$

\section{Introdução}

Sábado, 10 horas da manhã; um burro sem rabo ${ }^{2}$ pede passagem ao carro parado em fila dupla numa rua do centro de Belo Horizonte. Carlos, jovem de 25 anos que recolhe recicláveis urbanos, bate um bastão de metal numa garrafa de vidro, enquanto grita, tentando vencer o ruído da rua. Quer, com o som alto e intenso, chamar a atenção daquele motorista que parou inadvertidamente na sua rota de passagem. Numa piscadela, ali ao lado daquela cena, um longo tapete vermelho está insolitamente estendido na calçada. Seria para alguma celebridade? A passarela formada pelo tapete estreito que recobre um trecho do passeio público atrai o transeunte e o convida para ser uma pessoa muito importante. Enquanto durar sua passagem por aquele trecho cênico, colorindo de vermelho a trajetória dos passos apressados, o passante aciona o imaginário coletivo - próprio e da platéia que o aplaude - e se transforma em uma celebridade instantânea. As situações narradas ocorreram na Rua Padre Belchior, situada na região central da capital mineira. Era um dia de Temporada do projeto Nessa Rua Tem um Rio.

Este artigo, movido e alimentado por uma etnografia, traz um foco de luz para o diálogo entre a arte e a cidade, a partir de manifestações artísticas que ocorrem na rua, como as cenas descritas naquele sábado pela manhã. As dinâmicas urbanas e a eventual sensibilização que arte pode propiciar são o interesse da pesquisa. O campo empírico é o projeto de intervenções artísticas Nessa Rua Tem um Rio, promovido pelo Instituto Undió, uma organização não governamental (ONG) que atua em temas de arte e educação e que tem sede na referida rua.

O objetivo é analisar os sentidos atribuídos pelos sujeitos das intervenções artísticas esporádicas, transitórias e efêmeras organizadas pelo instituto e apresentadas a

\footnotetext{
${ }^{1}$ PUCMinas, Brasil. Email: fabiabaurre@gmail.com ORCID id: https://orcid.org/0000-0003-1350-2440

2 Termo utilizado nos estados de Minas Gerais e Rio de Janeiro que se refere aos coletores de materiais recicláveis e de detritos e que significa: “1.carreta de duas rodas que se puxa por dois tirantes dianteiros para transportar coisas diversas 2. Indivíduo que puxa essa carreta.” (Aulete digital -

http://www.aulete.com.br/burro-sem-rabo)
} 
céu aberto na Rua Padre Belchior. Especificamente, busco entender os modos de percepção e apropriação de gestores, artistas, vizinhos, comerciantes e pedestres -, aqui chamados fruidores, que vivenciam ações de arte do projeto Nessa Rua Tem um Rio, que tem a calçada como palco.

Sendo a rua um território que pode contemplar fazeres artísticos como a cena citada do tapete vermelho, uma micronarrativa urbana da artista Marta Neves intitulada "Pessoa muito importante", uma série de questionamentos emerge na contemporaneidade, em diálogo e em tensionamento com o espaço público. A arte consegue criar pontes e provocar sentidos no ambiente urbano da rua? Longe do lugar institucionalizado das galerias, museus e centros culturais, a arte que ocupa as calçadas interroga - ou quer interrogar - modos de olhar, interlocuções, vínculos e experimentações. Assim, no domínio das proposições atuais da arte, outros processos de subjetivação podem ser estimulados.

Este estudo discute a cena de uma metrópole que traz uma oposição de processos da funcionalidade inerente à rua - e dela inseparável - e as manifestações artísticas não padronizadas que se realizam na rua, em propostas para uma "cidade sensível" (Campbell, 2015; 2018). A discussão se dá na empiria, a partir da fruição específica e das inquietações que diversos atores fazem desses processos. Está em discussão a interferência artística na calçada da Rua Padre Belchior, que se transforma em um espaço privilegiado, semelhante a um palco (Fortuna, 2013), que pode forçar uma quebra na rotina e eventualmente provocar reflexões ou estranhamento para os sujeitos que estão na rua e que passam por ela.

Metodologicamente, este estudo é uma etnografia. Em realce, a etnografia da cidade, à qual tem contribuição da Etnografia da Duração. Rocha e Eckert (2013) apontam que os acontecimentos investigados na cidade são, cada um deles, "condição do ato de interpretação da cidade, cabendo ao antropólogo-pesquisador, situado na figura do narrador, tecer as matérias lembradas e evocadas das quais resulta seu trabalho de campo." (Rocha; Eckert, 2013: 13). As autoras afirmam que cabe ao antropólogo "o papel de mediador na agência de reatualização e retransmissão de fazeres e saberes tradicionais nas modernas sociedades complexas". Os recursos audiovisuais são proeminentes na produção antropológica, tornando-se instrumentos para um registro que proporciona um “diálogo vigoroso nas experiências etnográficas e uma das 
principais vertentes dos estudos sobre culturas contemporâneas.” (Rocha; Eckert, 2013: $10)$.

Neste trabalho, os registros fotográficos e audiovisuais foram elementos fundamentais para o entendimento e a construção das vivências dos fruidores. Tive acesso a fotos documentais de diversos eventos ocorridos na rua e estive presente documentando dezenas de outras em que pude gravar em áudio algumas entrevistas e fazer fotos do local, das pessoas presentes e de detalhes das obras, assim como fiz vídeos de algumas intervenções. Assim, pude ter momentos de revisão e de concatenação de ideais a partir do que foi registrado em arquivos midiáticos. A investigação etnográfica foi realizada entre fevereiro de 2016 e fevereiro de 2020. A imersão no campo partiu da descrição densa (Geertz,1989), em diálogo com a abordagem de Magnani (2002) "de perto e de dentro", que privilegia a vivência cotidiana dos atores sociais, numa interação com as pessoas que compõe esse cenário pesquisado, a participação da rotina nos dias de semana e nos rituais, sobretudo nos sábados pela manhã, quando são programadas as intervenções artísticas.

Ressalto que optei por apresentar as intervenções artísticas, que são chamados pelos gestores do Undió de temporadas, fora da ordem cronológica. Apresento-os de forma a ter, a cada um dos conteúdos, um encadeamento de propostas. Optei por manter anônimos os interlocutores - pedestres, comerciantes, moradores e voluntários "batizando-os" com novos nomes, à exceção dos artistas e gestores. Outro detalhe diz respeito a como optei por grafar a Rua Padre Belchior, com erre maiúsculo, trazendo, na minha percepção, identidade e personalidade únicas à rua.

Este texto se organiza em seis partes além desta introdução. Arte e espaço público tem sua discussão com autores como Canclini, Campbell, Raciére e Pallamin no item 1; no item 2, faço uma revisão elementar da arte contemporânea, em diálogo com performance e arte relacional; todo o caminhar da etnografia está no item 3, num trabalho de (re)conhecimento de território geográfico, social e humano. A Rua Padre Belchior e o Instituto Undió em sintonia com as intervenções de arte estão discutidos no item 4 e as intervenções artísticas na calçada são visitadas no item 5. As considerações finais apresentam os resultados encontrados e as conclusões inferidas a partir da investigação no campo e encerram este artigo.

\section{Arte e espaço público}


Na vida diária, ordinária e rotineira, momentos de "encontro" com a arte podem ocorrer como surpresas que o espaço público propicia. Canclini (2016) aponta esse vínculo inerente entre processos artísticos e sociais: "A partir do início do século XX a sociologia mostrou a necessidade de entender os movimentos artísticos em conexão com os processos sociais." (Canclini, 2016: 17).

Tendo a rua como cenário, o caminho envolto no enredamento desta aproximação vida e arte é quase tortuoso, como nos lembra Jesus (2015). Arte contemporânea e experiência estética amalgamam-se "como um processo de resistência diante das formas espetaculares que assediam as subjetividades." (Jesus, 2015: 2), numa sociedade do espetáculo estudada pelo filósofo Debord desde a década de 1960 e cada vez mais atual e potente neste presente midiático e audiovisual.

Arte e rua, nesse entendimento, confluem em um trecho da Rua Padre Belchior, no centro da cidade, em ações de intervenções artísticas do Projeto Nessa Rua Tem um Rio. Desde 2010, ações de arte propostas por artistas voluntários incitam uma descontinuidade do cotidiano de quem transita por aquele trecho, numa provocação para experienciar - ou não - momentos com a arte da contemporaneidade. No desenho das linguagens e práticas de arte, a arte urbana pode ser chamada de arte pública, arte relacional, arte contextual e até "situações". O nome adotado neste estudo é “intervenções artísticas” e será minha escolha ao me referir a cada prática de arte ou ao conjunto delas.

As obras de arte urbana, ao se apropriarem do espaço, envolvem em seus propósitos estéticos o trato com significados sociais que as rodeiam, seus modos de tematização cultural e política (Pallamin, 2000), estabelecendo significados sociais por meio das obras:

Os significados da arte urbana desdobram-se nos múltiplos papéis por ela exercidos, cujos valores são tecidos na sua relação com o público, nos seus modos de apropriação pela coletividade. Há uma construção temporal de seu sentido, afirmando-se ou infirmando-se. (Pallamin, 2000: 23).

A arte urbana é, para a autora, uma prática social que tem seus múltiplos significados evocados a partir dos modos de apropriação dos interlocutores. Para Pallamim há uma construção temporal de sentidos em que é valoroso "rever seus próprios papéis diante de tais transformações: quais espaços e representações modelam 
ou ajudam a modelar, quais balizas utilizam em suas atuações nesse processo de construção social." (Pallamin, 2000: 19). Cabe lembrar que os museus, galerias e espaços culturais são considerados espaços artísticos institucionais circunscritos ${ }^{3}$.

A fruição da arte no espaço público que move esta investigação tem como especificidade o recorte ainda mais delimitado de uma calçada, posto que as ações estudadas ocorrem na calçada em frente à sede do Instituto Undió ${ }^{4}$, que desenvolve as intervenções que são objeto de estudo. Leite (2004) nos orienta que nos espaços urbanos, ações podem atribuir sentido de lugar e de pertencimento, assim como as mesmas espacialidades podem influir nas construções de sentidos para as mesmas ações. Essa concepção nos faz inferir que as vivências de arte na rua - e naquela rua, em específico - são peculiares, conformadas pelas circunstâncias.

A rua é onde as diferenças se publicizam e se confrontam politicamente (Leite, 2004). Na perspectiva política há a partilha do sensível ${ }^{5}$, que se ordena pela política e pela estética, segundo Rancière (2005). O que se partilha? O tempo, o espaço, o tipo de atuação, sendo que a partilha trata do comum e ainda do específico, estabelecendo-se um "lugar de disputa" que determina competências e incompetências, a visibilidade e a invisibilidade, o pertencimento propriamente. Sob esta ótica propositiva de Rancière, as ações artísticas do Nessa Rua Tem um Rio oferecem um deslocamento estético e sensível dos fruidores e constituem-se, logo, ato de subjetivação política.

Se historicamente, a arte formal está nos espaços públicos por meio de esculturas e monumentos que saúdam conquistas e eternizam heróis em todo o mundo, mais recentemente as cidades acolhem novas possibilidades artísticas. Em meados do século $\mathrm{XX}$, os grafites e os pixos vieram ocupar muros, paredes, pilastras e monumentos nas vias públicas, enquanto as performances acontecem nas ruas. No Brasil, as ações performáticas de Flávio de Carvalho pelas ruas de São Paulo - Experiência $n^{\text {o. }} 2$ e

\footnotetext{
${ }^{3}$ A este respeito, existe larga bibliografia. Entre elas, destaca-se Brian O’Doherty, com o basilar "No interior do cubo branco: a ideologia do espaço da arte", que trata estes espaços como normativos, anódinos e orientados, em que o mundo externo não entra; o espaço é exclusivo e a estética é transformada numa espécie de elitismo social. "A obra é isolada de tudo o que possa prejudicar sua apreciação em si mesma” (O’Doherty, 2007: 03).

${ }^{4}$ O Undió desenvolve projetos de arte e cultura para crianças e jovens há mais de três décadas e será apresentado oportunamente.

${ }^{5}$ Expressão cunhada por Jacques Rancière na década de 1990. "Partilha significa duas coisas: a participação em um conjunto comum e, inversamente, a separação a distribuição de quinhões. Uma partilha do sensível é, portanto, o modo como se determina no sensível a relação entre um conjunto comum partilhado e a divisão de partes exclusivas" (Ranciére, 2005: 7).
} 
Experiência $n^{0} \cdot 3^{6}$ - são consideradas por Cocchiarale (2004) as primeiras manifestações da arte contemporânea e que ocorreram no espaço público.

Estudar as intervenções de artistas e coletivos de artistas e leigos que colaboram com as ações do Undió, implica em discutir a arte da contemporaneidade como encontro, afetação e criação de sentido em dado momento. Como pontua Geertz (1997), o processo de atribuir à arte um significado cultural é sempre um processo local e que também traz um "olhar da época", que é a bagagem cultural inerente ao momento. E ressalta a capacidade de criar sensibilidade, por meio da experiência coletiva:

A capacidade de uma pintura fazer sentido (ou de poemas, melodias, edifícios, vasos, peças teatrais ou estátuas), que varia de um povo para o outro, bem assim como de um indivíduo para outro, é, como todas as outras capacidades plenamente humanas, um produto da experiência coletiva que vai bem mais além dessa própria experiência. O mesmo se aplica à capacidade ainda mais rara de criar essa sensibilidade onde não exista. (GEERTZ, 1997a: 165).

Ganha relevância para este artigo menos o fato de o autor citar objetos artísticos, mas mais especificamente a capacidade que manifestações artísticas têm de criarem sensibilidade. Nesta abordagem, a arte que acontece na rua aciona tanto a experiência coletiva quanto a apresenta aonde ela não existia, eventualmente criando sensibilidade. As intervenções propostas pelo Undió trazem para a calçada experiências com a arte onde ela não estava ou não costumava estar. Cartaxo (2009) reforça essa dinâmica social quando afirma que a cidade, com seus movimentos, se converte em um reflexo do mundo e o artista utiliza, então, a cidade para ativar reflexões coletivas.

Campbell (2015: 23) afirma que os artistas que atuam na esfera pública buscam ativar o poder existente nas relações e nas pequenas ações “desestabilizando-o em pequenas, e às vezes singelas, utopias de transformação do comum, no sentido de transformação da realidade a sua volta”. Neste sentido, a arte contra a banalização do cotidiano pode ser entendida como "pequenas táticas que desmobilizam as práticas

\footnotetext{
${ }^{6}$ Experiência n ${ }^{\circ} 2$ foi o exercício de andar no sentido contrário ao de uma procissão de Corpus Christi, com chapéu à cabeça e Experiência $n^{\circ} 3$ configurou-se como um desfile pelas ruas com um traje masculino concebido para os trópicos: o New Look, como o chamou, era composto de saia e blusa em tecido translúcido. O artista chamava essas performances de experiências. Para saber mais ver (Moraes, 1986).
} 
sociais instituídas", interferindo sobre as estruturas tecnocráticas e "articulando-se sobre detalhes poéticos do cotidiano".

A perspectiva de arte que o Nessa Rua Tem um Rio aborda transita entre as possibilidades de resistência subjetiva na metrópole, em intervenções artísticas no espaço urbano realçando o direito à cidade e às experiências de significação do indivíduo, por intermédio da arte; uma guerrilha do sensível (Mendonça, 2006). Neste sentido, via espaços da subjetivação, construídos pelo sensível, que é material da arte, a experiência estética "atravessa e é atravessada pela experiência ordinária, provocando um estremecimento sutil, quase eventual, mas que nos permite vislumbrar (ou apenas pressentir) em meio à pobreza da nossa rotina, o que ainda não sabíamos ou não desconfiávamos possível", afirma Brasil (2006: 96-7).

\section{Das artes do agora: uma revisão elementar em diálogo com performance e arte relacional}

Para uma melhor apreensão do termo "arte contemporânea", conceito fundamental para o entendimento das articulações artísticas do Nessa Rua Tem um Rio, uma pincelada organizadora dos conceitos se faz necessária, como um sobrevôo que mapeia uma área a ser explorada. “Arte contemporânea” se trata de um jargão usual que enfeixa uma produção tanto teórica quanto conceitual e cria um estatuto - fato que explica a escolha -, em detrimento da expressão "arte da contemporaneidade", mais fluido e mais representativo, na minha percepção, para as produções atuais.

Nosso ponto de partida cronológico são os anos 1960, momento em que as artes inauguram o conceito do contemporâneo (Argan, 1992). Acontece o rompimento em relação à pauta moderna ${ }^{7} \mathrm{e}$ há destaque aos conteúdos audiovisuais - como processo e como materialidade -, com o rebaixamento de categorias específicas como pintura ou escultura, anulando classificações usuais até então. As linguagens se articulam cada vez mais, incorporando a dança, o teatro, a música, e outros fazeres artísticos.

\footnotetext{
7 O período moderno entre os anos 1900 e 1950 foi pleno de explosões criativas, momento de efervescência que impactou a contemporaneidade. Surgem, em sequência, e, em alguns momentos, em justaposição mantendo o ir e vir de motivações, os "ismos" (Canton, 2009). Fauvismo, cubismo, expressionismo, futurismo, dadaísmo, surrealismo, suprematismo, o construtivismo russo e a Bauhaus, entre outros. Em vivências prenhes de variedade e materialidade, propunham sínteses, abstrações, geometrizações e construções de formas inéditas.
} 
No sentido estrito do termo, arte contemporânea é a arte do agora, que desperta a simultaneidade ao se manifestar "no mesmo momento e no momento mesmo em que o público observa." (Cauquelin, 2005: 11). A arte contemporânea, que surge na continuidade da era moderna, "se materializa a partir de uma negociação constante entre arte e vida, vida e arte.”, afirma Canton (2009: 49). Para elucidar esta aparente disputa, Brígida Campbell, ela própria artista, além de pesquisadora, caminha em direção à arte fora do seu campo ao defender que

[...] os artistas de hoje não estão preocupados com as dicotomias entre arte e nãoarte, galeria-rua, objeto-experiência, [...] estão livres para criar obras sem categorias definidas e a transitar entre diferentes universos culturais da arte. (Campbell, 2018: $35)$.

A arte da contemporaneidade é chamada de arte pós-autônoma por Canclini (2016) para quem se trata de iminência que entrecruza práticas e teorias sociais com o trabalho artístico e as teorias estéticas. Corroborando esta perspectiva, Katia Canton (2009: 49) considera que: "Nesse campo de forças, artistas contemporâneos buscam um sentido, mas o que finca seus valores e potencializa a arte contemporânea são as interrelações entre as diferentes áreas do conhecimento humano.” A produção simbólica ganha espaço na articulação texto, som, imagem em movimento, há novas relações espaço-temporais e o intenso hibridismo entre suportes, domínios e possibilidades de criação, como pontua Eduardo de Jesus. ${ }^{8}$

Um importante embrião para a discussão das artes audiovisuais e a cidade foi a Internacional Situacionista, criada na Itália em 1957 por Guy Debord ${ }^{9}$, auto-declarado "doutor em nada" que defendia a mudança radical de toda a ordem, considerada aprisionadora. As manifestações propostas partiam de perambulações coletivas ao acaso pela cidade. Como prática da arte ligada à vida cotidiana, ao lazer e à cultura,

8 “O que ocorre é um trânsito entre os mais diversos suportes, indo do desenho em papel, passando pela pintura, performance, fotografia, instalações que, combinadas com opções e estratégias pessoais que incorporam técnicas bem distintas (tradicionais e novas), fazem da arte contemporânea um amplo e dinâmico território." (Jesus, 2016: 170).

9 Filósofo, cineasta e agitador cultural, Debord lançaria em 1967 "A sociedade do espetáculo", com conteúdo teórico que faz uma análise crítica da sociedade de consumo. O discurso libertário das 221 teses reunidas no livro ganhou força e reverberação com os acontecimentos de maio de 1968. E, em “Advertência da edição francesa de 1992", o próprio autor vaticina: "É preciso ler este livro tendo em mente que ele foi escrito com o intuito deliberado de perturbar a sociedade espetacular. Não exagerou nada." (Debord, 1997: 12). 
situacionistas estimulavam as reinterpretações do espaço com base na experiência vivida da deriva e do desvio para combater a alienação e a passividade.

Sobre o exercício crítico Situacionista, Paola Berenstein Jacques escreve:

A resposta do Situacionismo à cidade moderna contrapõe-se aos preceitos do urbanismo consolidado na primeira metade do século XX, propondo a experiência dos espaços urbanos não usuais de forma lúdico-criativa, a apreensão da cidade enquanto lugar do jogo e dos acontecimentos mais variados, espontâneos e efêmeros. À medida que as relações afetivas estabelecidas entre as pessoas e o espaço urbano passam a ser, para os situacionistas, o ponto de partida para o reconhecimento da cidade, a própria ideia de usuário e de usos da cidade é colocada em questão. (Jacques, 2003: 45).

O interesse dos situacionistas pelas questões urbanas repercutia a importância que delegavam à cidade "como terreno de ação, de produção de novas formas de intervenção e de luta contra a monotonia, ou ausência de paixão, da vida cotidiana moderna", comenta (Jacques, 2003: 13). A crítica ensejada pelas experiências de cinco décadas atrás permanece pertinente para o campo estudado, com proposições de experimentos não convencionais efêmeros e espontâneos das intervenções de arte do Nessa Rua Tem um Rio, sempre ocasionais e "impermanentes".

A arte política, engajada e contestadora, seguiu ganhando fôlego e lugar nos anos 1960-1970 em uma conjuntura de contestação social ${ }^{10}$. Corpos ativistas ocupavam espaços públicos - Movimento Hippie, o discurso pacifista de Martin Luther King e a luta armada dos Panteras Negras nos Estados Unidos. "É proibido proibir" era a máxima defendida nos protestos dos estudantes de Paris em maio de 1968. Esse quadro geral proporcionou a retomada da discussão da autonomia da arte e o deslocamento tanto de foco quanto das práticas - para os espaços não institucionalizados. Chegar às ruas foi um desdobramento natural. Os ecos da contracultura reverberavam pelo mundo em obras com autorias compartilhadas e experimentais. O Brasil, no entanto, vivia o ambiente de censura e perda das individualidades pós-golpe de 1964.

No fazer artístico, a ideia de fluxo, movimento, escoamento ganhou força. A exploração de sons e ruídos tirados do cotidiano ocupou lugar central na definição da atitude artística do Fluxus, que combina, ainda, conteúdos sinestésicos simultâneos,

${ }^{10} \mathrm{O}$ movimento Fluxus reforça a atitude de proximidade entre artistas e não-artistas em acontecimentos cênicos e happenings que buscavam a simplicidade diante do mundo, do fazer artístico e da cultura. Esses registros interdisciplinares e plurais se manifestam em múltiplas formas artísticas em diálogo e interação: artes visuais, fotografia, vídeo, música, dança, teatro, poesia e outras. (Campbell, 2018; Foster, 2014; Freitas, 2013; Zanini, 2018). 
estimulando os sentidos. As performances e os happenings se ligam ao teatro e à dança e convocam os espectadores à participação em espetáculos experimentais, muitas vezes descontínuos, sem foco definido, não-verbais e sem seqüência previamente estabelecida. (Lucie-Smith, 2006; Zanini, 2018).

Richard Schechner (2013) defende a idéia de que toda performance ${ }^{11}$ é um comportamento restaurado e traz a noção de trança, numa urdidura de elementos de rituais e de teatro. Rituais aqui compreendidos como sistemas de construção simbólica culturalmente construídos que compartilham uma ordenação que os estrutura, um sentido de realização coletiva com propósito definido e a percepção de que eles são diferentes do cotidiano (Peirano, 2002) ${ }^{12}$. No final da década de 1970, Schechner desenvolveu estudos sobre performance em parceria com o antropólogo Victor Turner, estudioso das simbologias subjacentes aos rituais. Ambos reconheceram a importância do conceito de ritual para o entendimento dos sentidos da performance a partir das quais populações que poderiam vir a entender umas às outras por meio das suas performances (Taylor, 2013: 11).

Claire Bishop (2004: 120), traz luz para o julgamento ético-político das relações produzidas por um trabalho de arte enfatizando que "Se a arte relacional produz relações humanas, então, a próxima pergunta lógica a se fazer é quais tipos de relações estão sendo produzidas, para quem e porquê". Notoriamente a arte urbana, sendo uma prática social (Pallamin, 2000), apresenta muitos significados que são construídos e apropriados pela coletividade. Esta questão nos é cara, pois a qualidade - em densidade, entendimento e motivação - das relações estabelecidas nas intervenções artísticas do Nessa Rua Tem um Rio são fundamentais para os efeitos observados e as reações percebidas em cada evento, apropriadas pelo coletivo.

A arte sempre foi relacional, em graus diferentes. Esta evidência parte da perspectiva orgânica de que é necessário haver uma presença específica, que é o espectador, para a apreciação da obra. Ademais, entre a obra e o espectador há sempre

${ }^{11}$ A Antropologia da Performance é um modo de avaliar a vida social como um conjunto de atos performativos, uma certa dramaturgia que fornece inteligibilidade. É o que estuda, na USP (Universidade de São Paulo), o Núcleo de Antropologia, Performance e Drama (NAPEDRA), liderado por John Dawsey.

${ }^{12}$ Rituais são entendidos, nesta lógica, como eventos "tanto ordinários quanto críticos [...] que partilham de uma natureza similar, um sentido de acontecimento cujo propósito é coletivo," (Peirano, 2002: 8). O rito foi retomado e recuperado nas décadas de 1970 e 1980, quando a preocupação etnográfica voltou a ter importância para a antropologia "agora não só como mecanismo bom para pensar, mas também ação social boa para viver”, para Peirano (2002: 24). 
um encontro, uma relação, uma interação. Arrisco dizer que, seja feliz ou frustrante, é deste encontro que se trata a arte. Ou, de forma mais enfática, "A resposta mais adequada para a obra de arte não é mais a veneração ou o respeito, mas o desconforto, a ruptura ou um desarranjo sem precedentes dos sentidos.", como dispara Kester (Stott, 2014: 77).

\section{Caminhar e (re)conhecer: passeios etnográficos pela rua}

$\mathrm{Na}$ etnografia de rua, "o perfil de uma comunidade, indivíduo e/ou grupo se configura aos poucos, pois o etnógrafo trabalha pacientemente a partir de colagens de seus fragmentos de interação." (Eckert; Rocha, 2003: 6). As autoras sugerem que o antropólogo vivencie o desafio da experiência formada pelo que chamam de 'morada de ruas', em que caminhos, ruídos, cheiros e cores - desenhados pelo próprio movimento dos pedestres e dos carros - sugerem as direções e sentidos que nos conduzem a certos lugares, cenários e paisagens. Meu objeto foi me comunicando novidades a cada visita, a cada interação com o campo. Eu saía de casa de uma forma e retornava transformada: inquieta e em busca de outras fontes, outros olhares, algo que criasse um possível diálogo ao qual eu não tivesse atentado (Geertz, 1989).

As observações foram registradas em caderno de campo, servindo como apoio e registro, anotações de considerações, insights e proposições. Indago àquelas pessoas, que se dispõem espontaneamente a conversar sobre a participação nas ações, suas impressões sobre a vivência com aquele trecho de rua antes e no dia das apresentações artísticas e suas impressões a respeito da experiência. Na inspiração de Rocha e Eckert (2013) fiz registros audiovisuais em formato de fotografias e vídeos, amplificando a coleta de dados e a capacidade de documentar o campo para ampliar análises por meio dessas representações (Becker, 2009) ${ }^{13}$. Desta forma, há a possibilidade de o leitor refletir, ele próprio, sobre a dimensão audiovisual do que está descrito textualmente, ainda que as imagens sejam representações e tenham o "recorte", ou a curadoria da pesquisadora.

Em dias em que não havia Temporada, me misturei ao ir e vir das pessoas. Fui cliente da loja de ferragens e da assistência técnica de celulares. Muitas vezes, optei por

\footnotetext{
${ }^{13}$ Uma representação é uma construção social, feita por meio de quatro fases: seleção, tradução, arranjo e interpretação, podendo ser um filme, uma fotografia, um mapa. "A representação é necessariamente parcial, é menos do que experimentaríamos e teríamos à nossa disposição se estivéssemos no contexto real que ela representa." (Becker, 2009: 31).
} 
tomar notas à distância. Postava-me na esquina e ficava observando os ciclos de movimentos humanos. Eu queria perceber o ritmo e o envolvimento das pessoas com as opções da rua em horários comerciais e à noite; em dias de segunda-feira a sábado e aos domingos.

Observava a rua e seus momentos inspirando-me no conceito de cena de Clark (2008), que se refere ao caráter qualitativo de um espaço: relaciona-se igualmente à expressividade daqueles que estão ali como freqüentadores e às práticas ali realizadas. Estruturas físicas, demográficas e atividades constituem a cena, que pode ser definida como um elemento urbano ou uma vizinhança ou ainda uma forma de vida. Quando não havia eventos no Undió, vivenciei dificuldades para fazer entrevistas como a desconfiança das pessoas, a falta de interesse em prestar informações e o desconhecimento a respeito da rua: "Nem sei o nome dela, passo aqui só para pegar o ônibus mesmo", ouvi mais de uma vez.

Pesquisar a própria realidade - esclareço que por oito anos (entre 1982 a 1990), morei a dois quarteirões da rua que decidi estudar - me faz caminhar sobre uma linha tênue que abala as convicções de uma jornalista que precisa da imparcialidade como pedra de toque. Em 2006, fui professora do curso de Multiplicadores do Projeto Undió em um módulo de dois meses sobre cultura e arte que se desdobraria no projeto Nessa Rua Tem um Rio. Me envolvo em indagações. O conhecimento prévio até que ponto pode ser imparcial? Ou ele seria essencialmente parcial? Estranhar o conhecido (Velho, 2003) seria possível? Vivencio que o processo de ver, ouvir e escrever (Oliveira, 1996), a pesquisa e a posterior escrita etnográfica, se recheiam de experiências auditivas, táteis, olfativas e visuais que suscitam insights (Ingold, 2008) e é inevitável incluir o sentir nesta produção escrita. E, retomando um pensamento weberiano, o pesquisador é um produtor de conhecimento, mas, é um cidadão. Minha experiência está indelevelmente ali no trabalho etnográfico (Peirano, 2008).

$\mathrm{Na}$ visita que faço à rua numa manhã de domingo ${ }^{14}$, em que tudo está quieto e sem tantos ruídos, sentimentos e lembranças afloram. Registro em palavras que eu sinto falta até do que não gostava e esse sentimento contraditório traz emoção para o meu deambular pela rua e arredores. Saudade do alto-falante do açougue que desde cedo de manhã anunciava as ofertas. Saudade do cheiro de pequi, enjoativo e "grudento".

${ }^{14}$ Comecei a ir a campo em 2016, no início do curso de Doutorado em Ciências Sociais. Sistematizando minhas visitas, a observação participante ia ganhando corpo e fôlego com o tempo. 
Saudade da correria para não perder o horário do ônibus para o trabalho. Tudo parece tranqüilo em confronto às memórias que tenho da vocação comercial que aquele lugar enseja.

Aquela manhã que me suscitou recordações afetivas sinestésicas foi uma das incontáveis oportunidades de "estar lá". Fiz longos e frequentes deslocamentos até a Rua Padre Belchior, ora pela manhã, ora à tarde e, em algumas ocasiões, à noite, oportunidade em que freqüentava os bares. Para entender a pulsação da rua, visitei-a em dias de semana e ainda aos sábados e domingos. A chegada ao campo sempre se deu sem "cena montada", o que foi valioso para a observação, que me proporcionou a compreensão das relações e práticas sociais. E assim, fui me embrenhando nas narrativas da rua, seus ocupantes temporários e seus movimentos diversos. Fácil identificar um dia de semana, uma manhã de domingo ou um fim de dia comercial.

Escolhi traçar trajetos e meios de mobilidade diferentes como forma de apreciar o caminho e a chegada ao campo, aliada à possibilidade de criar formas de desenvolver um olhar diferente do habitual. Algumas vezes, caminhei; outras vezes, fiz o trajeto em transporte coletivo; em poucas oportunidades escolhi ir de carro particular, o que se provava sempre um problema, devido à dificuldade de estacionar. Em qualquer das formas, nos deslocamentos percebia transições claras de uma área residencial para outra comercial: adensamento de lojas e de anúncios de prestadores de serviços, outdoors, concentração de sinais de trânsito, aumento no volume de veículos e de pessoas, anunciando a proximidade do Centro.

Seguindo a pé pelas calçadas da Rua Padre Belchior, me fixo na observação da parte edificada. Em sua maioria, são construções baixas, alguns prédios (com até três andares) e um único sobrado. Me atento às condições de conservação dos prédios, dos estabelecimentos comerciais e das calçadas. Algumas edificações têm fachadas descascadas em contraponto a outras que aparentam tinta recente; há alvenarias em condições desgastadas por rachaduras; há faixas de anúncios em tecido com letras quase ilegíveis devido ao pó de asfalto e à fumaça. As promoções de combos café e pão de queijo são anunciadas em placas escritas em giz nas lanchonetes e as ofertas formam um varal em papel no açougue.

Figura 1 - Fachada do açougue 
Fonte: Foto da autora, 2019

Nos pisos das calçadas, alguns trechos em pedra portuguesa em mescla preto e branco ainda resistem ao tempo. Aquelas pedras - as mesmas que eternizam as curvas da famosa calçada da praia de Copacabana - se contrastam com pedaços de cimento irregulares, desníveis, buracos e alguns trechos com piso tátil (em alto-relevo padronizado) para orientar e auxiliar a locomoção de deficientes visuais. Os contrastes descritos me chamam atenção e, na minha percepção, demonstram graus diferentes de cuidado; e, em certa medida, de envolvimento com a rua.

Figura 2 - Piso de asfalto e calçadas com coberturas portuguesa e tátil 
A área física da Rua Padre Belchior é arborizada e larga, mas é curta em extensão, conformada em apenas um quarteirão e meio. Em sua funcionalidade primordial, é uma rua de passagem, que dá acesso a corredores de trânsito. As três pistas do asfalto se dividem em estacionamento para carretas de aluguel - caminhonetes e carretinhas que têm estacionamento exclusivo naquele trecho -, pista de rolamento para veículos comuns e faixa exclusiva de ônibus, com linha azul pintada no chão pavimentado. No ritmo normal do horário comercial, compartilha os diversificados barulhos do trânsito de ônibus, carretas, veículos menores e o constante ir e vir de pedestres.

\section{Figura 3 - Trecho de rua em frente ao Undió}

Fonte: Foto da autora, 2018.

Figura 4 - Detalhe da rua 
Fonte: Foto da autora, 2018

Em época de manga ubá, o aroma da fruta (um tipo específico e muito perfumado), que é oferecida em carrinhos de mão pelos vendedores, se mistura ao cheiro de fumaça dos motores. A fuligem se acumula no banco do abrigo de ônibus e, no bazar de produtos usados, diversas mercadorias estão ao alcance da mão do pedestre interessado em uma televisão ou um par de botas. Café quentinho na lanchonete oferece o calor e o sabor da bebida e se mistura a outros aromas, cheiros, cores, ruídos diversos. Polissêmica e polifônica, a rua se apresenta (Canevacci, 1997). Em pouco mais de dez metros, naquele trecho de asfalto e gente, uma "sociabilidade barulhenta" (Arantes, 2000) se constitui. Várias cenas se confundem e aumentam o barulho: a caminhonete de carreto acelera, o ônibus que parou no ponto arranca e o vendedor de loteria grita a sorte do número 75: "É pavão, vai dar pavão na cabeça!".

Caleidoscópio urbano, todos os fragmentos possíveis se apresentam. Aquele cenário poderia se combinar com o ritmo do centro da cidade de uma metrópole qualquer do mundo globalizado. Para ilustrar as impressões da diversidade que se somam no meu caderno de campo, anoto: "Alheia a qualquer discussão, a árvore de ipê rosa vai singelamente colorindo de rosa o asfalto da rua Padre Belchior, com suas flores, como se construísse um poema urbano de flutuações e pousos". Percebo o quanto aquela rua e a vida que pulsa ali me afetam.

$\mathrm{Na}$ etnografia de rua, "o perfil de uma comunidade, indivíduo e/ou grupo se configura aos poucos" (Eckert; Rocha, 2003: 6) e eu, estando lá, fui construindo minhas colagens dos fragmentos de interação com a balconista da lanchonete, com o vendedor de flores e com o dono do bar. Foi nessa, e dessa, trajetória múltipla que engendrei e compreendi o exercício etnográfico. Durante o trabalho de campo, percorri a rua até que pudesse entender sua realidade aparente no tecido urbano e saber de cor seus marcos visuais.

A empatia, eu ia adquirindo com os relatos. "Ah, sei demais dessa rua, viu, menina?! O rio passava aqui uns 50 anos atrás e tenho saudade", reflete Teles, antigo morador com quem me encontrei ocasionalmente numa manhã de sábado. Golpe de sorte da pesquisa, que nos brinda com encontros inesperados. O exercício que meu interlocutor faz torna compreensível uma geografia fantástica. Vogel e Mello (2017: 46) para quem a rua "é um universo de múltiplos eventos e relações", chamam de 
geografia fantástica essa "cartografia" de objetos que tratam da evocação da memória. $\mathrm{Na}$ leitura arqueológica urbana por meio de relatos do que foi vivido, os interlocutores trazem fatos que evidenciam, em uma paisagem urbana imaginária. São lugares que não mais existem, mas que podem ser resgatados do esquecimento pela força da memória acessada por antigos moradores.

Em tom de nostalgia, apontando para os estacionamentos privados dos dois lados da rua ele comenta com veemência e sem esconder sua indignação: "É triste pensar que morava gente ali e ali, em espaços que agora são lugares de parar carros”. No exercício da memória, ele traz à luz suas recordações afetivas e os usos que, para mim, são apenas intuídos. Esse conjunto de reminiscências minhas e do meu interlocutor atuou como pistas para pensar sobre a interdependência do esquecimento e da memória vivida na cidade. "A cidade, a rua, o bairro nos habita como espaço vivido, como a profundeza de um poema" (Eckert; Rocha, 2003: 6). As autoras analisam a obra poética do escritor francês Georges Perec, que faz uma etnografia da rua em que viveu $^{15}$. No documentário, por meio do resgate de fotos antigas, há uma reafirmação de que não se pode reviver o passado sem o encadeamento em um tema afetivo necessariamente presente.

A rua, em sua funcionalidade, propõe o contato entre pessoas de várias origens sociais como a interação do trabalhador informal que atua como vendedor ambulante de óculos escuros com a estudante adolescente de classe média. Em pé e do ambiente público, ela experimenta três modelos e compra um par no modelo "lançado recentemente", como diz o vendedor reforçando o apelo da novidade.

Há, porém, diversos acontecimentos que não pressupõem interação - ou, ao menos, ela não é óbvia e talvez seja inquietante. No fim do dia de trabalho, o relógio marca $18 \mathrm{~h} 20$ de uma quinta-feira, muitas pessoas aguardam o transporte coletivo. Desconhecidas entre si, algumas aliviam o estresse da espera e o cansaço do dia ouvindo algum áudio no celular, com os fones enfiados nas orelhas. Os fones parecem ser armadura contra ruídos e interferências externas ou contra uma eventual interação humana. No ponto de ônibus, aquela pequena multidão - 15, talvez 20 pessoas - divide o espaço e o silêncio. Abstraio-me na observação.

Aquele momento me trouxe uma citação de Gabriel de Tarde, para quem "A conversação é a mãe da polidez. Isso acontece mesmo quando a polidez consiste em não

\footnotetext{
15 Trata-se da Rua Vilin, que teve seus relatos e vivências transformado em filme. En remontant la rue Vilin 1992 (Voilat, 2016).
} 
conversar." (Tarde, 1992: 141), trecho que faz muito sentido ali naquela situação da rua. Em silêncio, há uma dimensão comunicativa, um grau de "conversação", que ocorre pelo comportamento reflexivo naquela experiência urbana. Enquanto aguardam pelo transporte urbano, aquelas pessoas tão diferentes se assemelham.

\section{Sobre a rua, o Instituto Undió e as artes: diálogos prováveis}

O Instituto Undió é uma Organização Não Governamental criada há 35 anos pelas artistas Júlia Portes e Thereza Portes (mãe e filha) com o objetivo de promover ações de arte por meio de projetos sócio culturais. São oferecidas oficinas itinerantes de teatro, música e artes plásticas para crianças e adolescentes, que são acordadas com instituições parceiras, garantindo a gratuidade das iniciativas. Desde 2006, o Undió tem sede no número 280 da Rua Padre Belchior, um sobrado de 1930 (Figura 5) que já foi residência da família e é o espaço em que se desenvolvem as oficinas de arte e expressão plástica. E, em frente ao sobrado, na calçada, ocorrem as ações variadas de arte - as intervenções artísticas.

\section{Figura 5 - Sede do Undió, na lateral da parede/fachada a inscrição "Nessa rua tem um rio", à direita na foto}

Fonte: Instituto Undió (2017)

A Rua Padre Belchior tem sua origem intrinsicamente ligada às águas abundantes na área escolhida para sediar a nova cidade. Antes de ser rua, ela era rio. Impelida pela força das águas do Córrego do Leitão, que serpenteava pelo terreno, a rua 
surgiu antes como margem, como borda do traçado fluvial natural. Como não existia na planta original da cidade inaugurada em 1897 (Borsagli, 2014), um decreto $-\mathrm{n}^{\mathrm{o}} .43$ de 7 de setembro de $1929^{16}$ - criou a rua Padre Belchior, aberta oficialmente três décadas após a inauguração de Belo Horizonte. O registro fotográfico (Figura 6) ilustra a abertura da rua em 1928 em que se pode ver,em detalhe no canto direito, o guarda-corpo que limita o rio,correndo a céu aberto ao longo da rua.

\section{Figura 6 - Trecho da rua (em obras) em 1928, tendo o Córrego do Leitão canalizado ao longo do trecho}

Fonte: (CURRAL DEL REY, 2010)

Nos dias de hoje, quem se movimenta pela rua a pé, de carro ou de ônibus não percebe indícios de que ali há um rio, que se tornou invisível. Atualmente capeado, num processo de cobertura que começou na segunda metade da década de 1960, o Córrego do Leitão foi escondido pelo asfalto. Nesse processo, a rua "apagou" o rio. Ao evidenciar o rio no nome em homenagem ao curso d'água invisível, o projeto artístico traz de volta o córrego, resgata o que estava submerso e evidencia a memória da cidade. Em lembranças recheadas de afetividade, Júlia conta que o nome "nessa rua tem um rio" veio como um presente espontâneo: “Aqui em frente à casa, eu contava aos alunos que a rua era muito diferente no passado e que, mesmo escondido pelo asfalto, nessa rua

\footnotetext{
${ }^{16}$ O artigo 3o determina: "A rua marginal do córrego do Leitão, no trecho comprehendido entre a Avenida Paraopeba e a rua Santa Catharina, passará a se denominar Padre Belchior”, grafia da época, em decreto assinado pelo prefeito da época, Christiano Machado. (Belo Horizonte, 1929).
} 
tem um rio, o Córrego do Leitão. Pronto; foi assim, quase numa frase de efeito, que veio o nome do projeto", recorda.

Undió, no idioma banto, quer dizer casa. Esse universo simbólico que traz consigo o imaginário de um lar é reforçado na descrição da organização que está no site (Instituto Undió, 2012) ressaltando que "Na nossa casa educamos através da arte". E, realmente, no endereço em que funciona o instituto, a aura de um lar ocupado e em funcionamento está na cozinha cheia de utensílios, no armário debaixo da pia com material de uso coletivo, na área de serviço, com bacias de alumínio e panos de prato pendurados num varal de corda, nas flores e folhagens plantadas nos vasos que ornam a entrada da casa.

A casa pertence à família Portes desde sua construção, foi residência tanto da mãe quanto da filha e conserva seu padrão arquitetônico e de interior originais. Em entrevista $^{17}$, Júlia Portes conta que o pai, médico, sempre atendia consultas ali, sem cerimônia ou hora marcada. "Era movimento o tempo todo. Minha mãe sempre tinha um cafezinho fresco coado para os pacientes e seus acompanhantes", recorda. A porta (Figura 7) em modelo vai-vem em vidro emoldurado em madeira, que faz parte da decoração e da funcionalidade da casa, conserva a informação: Consultório Médico Doutor Geraldo Portes.

Figura 7 - Porta do antigo consultório

\footnotetext{
${ }^{17}$ Realizada em 12 de novembro de 2016
} 
A porta poderia ser uma relíquia, no entanto, seu estado ótimo de conservação compõe perfeitamente o ambiente do sobrado, e me traz a sensação de que a qualquer momento possa passar por ali um paciente em busca de alívio para uma dor qualquer. Essa viagem a um tempo que não me pertenceu aguça meu olhar para todos os detalhes da casa (Figuras 8 e 9). Atento-me para alpendre com vasinhos de plantas, as cadeiras de ferro pintadas de banco, a sopeira de louça fina colocada na porta de vidro do móvel de buffet da copa, os tacos brilhantes de madeira do chão. São todos indícios de uma nesga do tempo, um reviver na primeira metade do século XX.

Figura 8 - Área de serviço da casa

Figura 9 - Júlia assentada na cadeira na varanda do Undió 
Desde que foi criado, o Undió conserva característica fundante que é a partilha de experiências e a troca cultural tendo a arte como propulsora e linguagem unificadora. As intervenções pretendem estabelecer uma relação mais próxima com o cotidiano da rua através da arte, como fica evidenciado em texto oficial:

O projeto Nessa rua tem um rio propõe interferências poéticas na Rua Padre Belchior e arredores, e um convite para pequenas 'interrupções' nos hábitos e ritmos usuais do centro da cidade, como possibilidade de inaugurar novas leituras e pontos de vista sensíveis sobre o cotidiano da e na cidade e suas possíveis (e infinitas) 'entrelinhas', sobre arte, memória, corpos e pensamentos. (Instituto Undió, 2012)

O projeto Nessa Rua Tem um Rio é evento de natureza esporádica, portanto não periódica e não regular que ocorre na Rua Padre Belchior. Uma de suas atrações, o Café Comunitário também é denominado pelos conhecidos e amigos do Undió como "Café da Thereza", oferecido para todos e para quem quiser participar constitui-se, no contexto do projeto Nessa rua tem um rio, uma intervenção artística urbana. Atua como partilha do sensível, representada por uma xícara de cafezinho coado na hora, acompanhado de biscoitos, pães e bolos. 
Comerciantes, moradores e transeuntes do local, quando participam das ações propostas, frequentemente chegam devagar e lançam olhares curiosos. Às vezes andam com pressa e titubeiam entre parar ou seguir. Uma pergunta recorrente que pode ser traduzida por “o que era aquilo?" surge quando são questionados sobre as intervenções que presenciaram. Sob os olhos dos gestores e artistas, as intervenções são ações de arte para a comunidade, mas que não apresentam a arte na acepção que a palavra tem no senso comum. Para eles, cada ação ativa a participação, experiência e o afetamento que a arte pode propiciar.

A cidade em contato com a arte provoca boa interlocução com as intervenções artísticas a serem analisadas na discussão que Jacobs (2011) alimenta. Apesar de desenvolver estudos que afetam especialmente a arquitetura das cidades, a autora traz o elemento humano em afetação todo o tempo: pondera que "arte é arbítrio, simbolismo e abstração" frente à abrangência e complexidade infinitas da vida.

Precisamos da arte, tanto na organização das cidades quanto em outras esferas da vida, para ajudar a explicar a vida para nós, para mostrar-nos seus significados, esclarecer a interação entre a vida de cada um de nós e a vida ao redor. (Jacobs, 2011: 415).

Para trazer ainda mais adequação a este estudo, Jacobs trata das ruas e das calçadas como órgãos vitais da cidade, cenário da atividade do Undió. E, buscando na análise envolvente de João do Rio, que desvenda com riqueza de detalhes as ruas, seus tipos e atividades e seu espírito, "[...] a rua é um fator da vida das cidades, a rua tem alma!." (Rio, 2008: 29) e, para ele, esta é uma "alma encantadora"18.

Foi com carga de ativismo, tanto ambiental quanto artístico, que a $1^{\mathrm{a}}$ temporada do projeto Nessa Rua Tem um Rio aconteceu. O artista Wilson de Avellar apresentou a performance "Eu Rio" em outubro de 2010, na temporada de estréia, tendo como protagonista o Córrego do Leitão. Avellar se lançou ao chão e simulou um nado a seco, serpenteando seu corpo em pleno asfalto entre a Praça Marília de Dirceu e a Rua Padre Belchior - por onde correm as águas do córrego -, seguindo a guia do meio fio. Cerca de 12 quarteirões separam os dois pontos.

\footnotetext{
${ }^{18}$ Cabe aqui menção ao fato de que Jane Jacobs estuda a realidade das cidades americanas e João do Rio investiga e vivencia, em sua obra, o Rio de Janeiro. Ambos abordam realidades próprias que, entretanto, não se restringem àquela localidade ou contexto histórico, podendo ser referências para a interpretação de outros casos e, em especial, do Instituto Undió.
} 


\section{Figura 10 - Eu Rio - ação-intervenção}

Fonte: (AVELLAR, 2010)

Para o artista, era essencial chamar a atenção dos transeuntes para um fato que não pode evanescer: o rio está vivo ali. "Foi o ponto de partida para a minha criação esse grito, um libelo mesmo, que pudesse trazer a consciência das pessoas para o valor, a importância das águas." (Wilson de Avellar). ${ }^{19}$ Ao parar em vários bueiros e nas grelhas incrustadas no asfalto, colava o ouvido naquelas ferragens para ter a certeza de ouvir o rio correndo. Deixou explícita a existência do Leitão que a pavimentação das ruas esconde e apontava para a temática premente do uso da cidade e dos corpos que estão no espaço urbano:

Fiz a escolha de ter a rua como espaço de apresentação e de escuta. Vivência da rua pelo que está por emergir como um ressalto, do que está suspenso. E o corpo é colocado na rua, que é um lugar violento, sem espaço para o humano e onde apenas a máquina prevalece. Existe a possibilidade da cartografia de cada um. Há muita responsabilidade, mas outra ordem de responsabilidade da audiência. (Wilson de Avellar). ${ }^{32}$

Ao longo da ação artística, munido de cotoveleiras e joelheiras e de um barquinho de papel, o artista discutia a transitoriedade e a fragilidade frente ao rio e à cidade asfaltada que o engoliu (Figura 10). Presente àquela performance, eu entendia a força do gesto envolvido na ação, mas também me preocupava com a segurança dele.

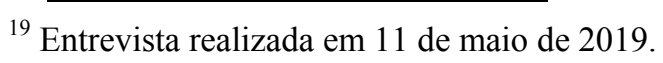


Em seu entorno havia sempre muitas pessoas, talvez curiosas, talvez querendo ajudar aquele homem jogado ao chão. Mas, na chegada ao Undió, Avellar demonstrava muito contentamento, apesar do nítido cansaço corporal. "O patrimônio etnológico de cidades se transforma num espaço afetivo e poético" (Rocha; Eckert, 2013: 23) e aquela manifestação era uma evidência disso.

Prossigo nas minhas deambulações pela rua e nas investigações de personagens que sempre têm histórias para contar e oferecem um olhar sobre as ações que estudo. "Eu já te vi andando por aqui algumas vezes. Mas o que é mesmo que você quer?", me inquire Breno, o paneleiro que trabalha em frente ao Undió consertando panelas e fogões desde 1994 (Figura 11). Explico sobre o trabalho que desenvolvo e ele comenta:

A mesa do café já vi várias vezes, já participei. Sempre quando posso vou lá tomar um café e comer um bolo. Ali todos chegam, trocam idéia... Não fazem diferença das pessoas, sabe?! (diz querendo que se entenda que não há distinção social) O que fazem? Ah, muitas coisas. Já plantaram árvore... Já varreram a rua - o que achei muito bom, porque eu vivo varrendo aqui em frente! Tem sempre movimento. Elas trazem pessoas que usam droga e estão em recuperação e fazem batucada aí. Tem uns que zoam e ficam rindo... eu explico o que acontece ali. Por alto, né? Falo que era uma mulher que há muito tempo atrás tinha mania de fazer broa e café e dava pras pessoas. (Breno, Paneleiro).

A entrevista com Breno trouxe a pessoalidade do olhar de quem vivencia a rua. Ele fala como um prestador de serviços, mas é um atento observador dos ritmos daquela via.

\section{Figura 11 - Loja de consertos}

Fonte: Foto da autora, 2019

Saber o que pensam os comerciantes nem sempre foi tarefa confortável durante as entrevistas. Monossilábico inicialmente, Walter José, dono de lanchonete, aos poucos 
e com relutância, falou que conhece Thereza e Júlia e acha "interessantes e boas as ações de teatro e de festa que fazem". A vendedora da loja de eletrônicos Iara já viu muitos eventos na rua e sabe que "teatro o pessoal adora. Mas a pergunta que sempre fazem é se é de graça. Eu atravesso a rua e vou tomar café sim, mas não me envolvo muito", confessa. "Uma ONG, é? Já vi algumas coisas acontecendo que me chamaram a atenção, mas acho que nunca presenciei nada de arte”, comenta José, atendente da relojoaria, há três anos trabalhando no estabelecimento. Anoto no meu caderno uma frase que me ocorreu diversas vezes nas entrevistas casuais que faço: "será arte?"20

Os fatos narrados poderiam acontecer em outra cidade, dadas às características dos encontros humanos no sentido de comum. Vogel e Mello discutem a vida comunitária como

[...] um conjunto de desempenhos suportados por 'palcos', por 'cenários'. [...] Jogos, reuniões, festas, encontros, cerimônias e atividades assemelhadas que se oponham às idéias de privacidade e de intimidade encontram na rua seu lugar ideal. É aí que deve estar o que é de todos. (Vogel; Mello, 2017: 35).

A ocupação e apropriação dos espaços urbanos são, na perspectiva de Thereza, possibilidades de "ver a cidade sob um novo ângulo" (Portes, 2015: 50). A rua passa a ser uma espécie de experimento artístico e das emoções, com outra função além de ser passagem ou espaço para atividades comerciais. A atividade artística pretende deslocar a atenção dos transeuntes (eventuais participantes) da passividade do deslocamento funcional e convidá-los a repensar suas relações com a cidade. O formato flexível, democrático e gratuito das intervenções propostas evidencia a vida da ou na rua e a convivência em comunidade. "Bastam a rua, a vida, as pessoas", comenta Júlia Portes no blog do projeto em que enaltece esta circunstância que une a rua ao convívio social.

"Thereza é muito inaugural! Topa as idéias e vibra com elas", comenta Marta Neves $^{21}$ artista plástica, autora da obra "Pessoa muito Especial" que estendeu o tapete vermelho sobre o cimento da calçada. "Participo do Nessa Rua Tem um Rio desde 2011

${ }^{20}$ Cada vez que escrevo esta dúvida no meu caderno, inevitável pensar no poema de Ferreira Gullar, "Traduzir-se", que reverbera questões opostas convivendo num mesmo ser e, nessa dualidade, quer saber se aquilo - o viver - é arte: "Uma parte de mim é todo mundo/ Outra parte é ninguém / Fundo sem fundo/ Uma parte de mim é multidão/ Outra parte estranheza e solidão / Uma parte de mim, pesa/ Pondera/ Outra parte, delira/ Uma parte de mim almoça e janta/ Outra parte se espanta/ Uma parte de mim é permanente/ Outra parte se sabe de repente/ Uma parte de mim é só vertigem/ Outra parte, linguagem/ Traduzir uma parte noutra parte/ Que é uma questão de vida ou morte/ Será arte?/ Será arte?” (Gullar, 2017: 30).

${ }^{21}$ Entrevista ocorrida em 03 de abril de 2019. 
e já te digo que são as intervenções mais legais que faço”, responde nitidamente feliz com a recordação que passa pela sua mente. As discussões que a arte engendra para aquele espaço são a gênese de cada trabalho, ela conta:

\begin{abstract}
Antes de eu criar uma obra para apresentar no Nessa Rua Tem um Rio, penso no que ficaria bom para o local: penso na resposta da e para a rua e as imediações. E penso de uma forma mais ampla sobre o sentido para aquele centro nevrálgico, penso na circulação de pessoas... penso naquelas que estão paradas nos pontos de ônibus e nos sinais e também penso sobre o próprio espaço do Undió. Cada obra tem uma especificidade, tem muito essa coisa de pensar para o local, refletir sobre ele. (Marta Neves, artista plástica).
\end{abstract}

Sobre a arte na rua, em caso específico do Nessa Rua Tem um Rio, e de forma geral, ela afirma que

O termo arte desimporta. Pra mim são intervenções. A priori! Posso gostar mais ou menos, não importa. A palavra arte não aparece, talvez, para quem não transita no meio. Mas isto não tira o valor das ações como ações de arte, sabe? O que mais importa é que "essas coisas" estejam ali, que a idéia de arte esteja disseminada ali. (Marta Neves, artista plástica).

Pequenas interrupções no cotidiano atuam como os contrausos, respaldados por iniciativas da arte como o CineÓ, com sessões esporádicas de filmes projetados na parede da casa do Undió. Para o diretor e videomaker Alexandre Pimenta, que já produziu alguns filmes para o projeto e que organiza as sessões, está certo de que "tudo que acontece aqui é arte". À esta certeza ele acrescenta o aspecto da ocupação e do fato de que a arte pode estar em lugares hostis: "Além de ser arte, é resistência porque é democrático". É o mesmo pensamento de Raissa Angrisano, formada em artes plásticas e que cuida da gestão administrativa do Undió desde 2008 - como voluntária, como contratada e outra vez como voluntária, sempre de acordo com a verba de patrocínio:

Aqui, a essência é ser sempre resistência. Existe uma acessibilidade muito grande, das pessoas e das ideias. É ouvir a voz de todos. Cada intervenção é um espaço de respiro na cidade, torna a arte mais democrática, traz reflexões. (Raissa Angrisano, artista plástica).

Ela acredita que as intervenções são estratégicas para o conjunto de relações, que se fortalecem e está certa de que o público que constitui a audiência é alcançado.

Eventos na rua são focos de autonomia e resistência que reforçam os processos de subjetivação no espaço urbano. acontece "gerando interrupções, processos poéticos e 'engrossando' o fluxo criativo e artístico da arte na cidade que se soma, assim, aos 
fluxos de resistência cultural e produção do espaço nas cidades contemporâneas." (Campbell, 2018: 21). São estratégias coletivas de apropriação da cidade, em ações coletivas livres, sem hierarquia, criativas e estéticas. Mendonça, Moriceau e Paes (2015: 7) chamam estes grupos de "guerrilheiros do sensível”. Nestes eventos,

[...] o resultado é incerto, com possibilidades de advir algo imprevisível, potencialmente liminar", afirmam e complementam: "Se há felicidade é a da criação, a do encontro. O que está em cena não vale pelo que representa, mas pelos pensamentos que cria. (Mendonça; Moriceau; Paes, 2015: 8).

Articula-se o exercício do imaginário nessas manifestações espontâneas. Além disso, trata-se do "direito à cidade", exposto e defendido por Lefebvre em 1967 (livro homônimo) como queixa e exigência; retomado nos anos 2000 (Harvey, 2014) ${ }^{22}$ no sentido da liberdade de reinventar, de forma coletiva, as experiências de significação do indivíduo.

\section{As intervenções artísticas na calçada: café, tapete vermelho e outros convites}

“As calçadas pertencem às casas, o que não significa que sejam parte destas como propriedade. Seu caráter público contrasta, por vezes, com as formas pelas quais são circunstancialmente utilizadas." (Vogel; Mello, 2017: 73). Assim, os usos tanto privados quanto públicos se impregnam de uma intrigante dialética vivenciada pelos fruidores. São performances, instalações, exposições de arte e alguns momentos de interação entre os passantes, que pode ser uma interferência na rua como, por exemplo, atividade de varrição coletiva, troca de mudas, banho de balde ou montagem de uma mesa farta com café e quitutes. O tema central, da rua e do rio, que inspira os projetos artísticos e instalações, faz uma calorosa ligação entre o interior e exterior em muitas dimensões: o rio e as bordas, a rua e a calçada, o público e o privado.

O Café Comunitário, atividade que o instituto organiza, acontece com ou sem outra apresentação artística explícita, já que para Thereza Portes, é iniciativa artística na sua forma mais envolvente e pode ser compreendido como um ato de sensibilização das pessoas. Ela não se preocupa em rotular como arte, ou melhor, evita de fazê-lo, e apenas

22 "O direito à cidade é, portanto, muito mais do que um direito de acesso individual ou grupal aos recursos que a cidade incorpora: é um direito de mudar e reinventar a cidade mais de acordo com nossos mais profundos desejos.” (HARVEY, 2014: 28) 
comenta se tratar de "uma iniciativa sensível". Aos olhos do público e devido ao acesso democrático, o café talvez seja a intervenção mais atraente e interpelativa e que se destaca.

Oferecer o café ocorre de uma maneira ritualística. O pó é coado na frente de todos, instantes antes de ser degustado, em um filtro de flanela apoiado num suporte metálico, tendo o bule esmaltado como recipiente. Esses itens e a forma de fazer "são tipicamente mineiro, em especial das cidades do interior do Estado", como afirma $J_{u ́ l i a}{ }^{23}$, demonstrando orgulho por manter a tradição. "Assim é como minha mãe coava café". Em sua fala e por sua expressão, é possível observar o resgate de um gesto imbuído de saberes e tradição: seja pela hospitalidade ou pela repetição de uma prática familiar. Ação esporádica, sem periodicidade definida e sem custos para quem participa, encerra em si um apelo repleto de estímulos sensoriais em cores, formas, gosto - e broa de fubá, bolo, pão fatiado, biscoitos de polvilho abrigados caprichosamente em cestinhas com um guardanapo embaixo - e o aroma do café (Figura 12).

\section{Figura 12 - Detalhe da mesa de café}

Fonte: Foto da autora, 2018

“Coisa estranha... É uma ação social?”, pergunta um jovem de bermuda e boné, que pode perfeitamente representar inúmeros outros pedestres que por ali passam e param. "Ué, o que é isto?”; “Pode comer?”, escuto de transeuntes. "Que bom gosto!

\footnotetext{
${ }^{23}$ Entrevista realizada em 12 de novembro de 2016.
} 
Que xícaras bonitas”, ouço de uma senhora. Quem são os protagonistas? Seria a mesa ou os convivas? Acredito que um não existiria sem o outro e decido por considerar a todos protagonistas. Esse ritual, que tem tom festivo, possibilita uma interação momentânea entre diferentes personagens: se olham, falam, comentam sobre os sabores e sobre o café ou sobre a vida e o cotidiano, numa espécie de comportamento comunicativo (Goffman, 1999), numa interação não-focalizada, fruto da simples copresença, ou como interação focalizada.

Frente ao inusitado, que é a ocorrência do café na calçada, e da nova e incomum sociabilidade no espaço da rua que provoca interação, ocorre um "choque de sentidos", como menciona Pallamin (2000). É possível ouvir comentários variados, como por exemplo, "Nem sou cafezeira, mas gostei mais da socialização do que do café", afirmou uma senhora. "Ah, que café ótimo, me lembro da fazenda da minha avó vendo esse coador de pano", recordou Guilherme, bancário. Essas declarações combinam com os desejos de Thereza e Júlia, de provocar pensamentos sobre uma cidade mais sensível e de estimular a memória afetiva.

O Café relativiza duplamente as fronteiras entre o público e o privado, desafiando a polarização das entidades morais casa-privado e rua-público (DaMatta, 1997). Compartilhar pães, bolos e café à mesa é vivência típica do âmbito doméstico da casa, da cozinha, da mesa e da família, diferente de beber e comer no espaço público da rua, em pé e com desconhecidos. No entanto, o recipiente que contem a bebida é um xícara que poderia ter saído do armário de louças da residência daquela pessoa que sorve o café.

Nem todas as pessoas que participam do ritual do café comunitário, são “desconhecidos", não raro existem os integrantes corriqueiros daquele trecho de rua, que são habituais "convidados", como o vendedor ambulante de óculos de sol de nome Genaro. "Sou vendedor há mais de 30 anos e sempre passo por aqui. Esta rua é muito barulhenta. Mas é boa pra vendas. Quando tem café, paro, observo e tomo uma xícara; tem pessoas muito diferentes nesses dias, mas também tem aquelas de todo dia", relata. Em uma mão ele segura o mostruário de vendas em isopor com os modelos de óculos fincados e na outra segura a fatia de bolo que degusta e encerra assim nosso diálogo com um meneio de cabeça. ${ }^{24}$

\footnotetext{
${ }^{24}$ Entrevista realizada em 12 de maio de 2018.
} 
A calçada, como espaço público, é quase como o coração - numa analogia à sua importância - da cidade, numa síntese da vida pública informal. Nela se reúnem pessoas que "não se conhecem de maneira íntima, privada, e muitas vezes nem se interessam em se conhecer dessa maneira." (Jacobs, 2011: 59). Jane Jacobs afirma que esta é a grande "serventia" da cidade, em que os contatos estão além da vida privada e que se constitui um pressuposto de apoio que é a confiança.

A intervenção artística nomeada de "Pessoa muito importante" (Figura 13), numa ironia com o termo em inglês VIP -Very Important Person que abriu este texto, obra assinada por Marta Neves, sugeria uma passarela improvisada para um desfile de figurinos urbanos representados pela gari, pelo coletor de material reciclável, pela senhora com sacola de feira, entre tantos outros, que com seus passos cadenciados, desfilavam na imaginária cena para celebridades. Aquele espaço acarpetado vermelho, cria, na minha concepção, uma limitada "ilha" retangular improvisada na cidade que traz visibilidade: na rua, para a rua e da rua.

Acanhada, a senhora segurando a mão de uma criança resiste, mas é convencida pela menina que pisa decididamente no tapete e se diverte com a situação. A gari, vestida em seu uniforme laranja nem titubeia: caminha pelo tapete e ainda ensaia passos de um sambinha, abraçada à vassoura. Naquele momento, ela se transforma na orgulhosa porta-bandeira da escola de samba do coração que abraça seu panteão e se empolga no bailado. Muita gente, porém, desvia do tapete e alega não querer "pagar mico" ou se atemoriza no caso de fazer alguma coisa errada pisando ali; e assim, seguem sendo anônimos passantes.

A gari que varre a rua e o office boy - ele também faz questão de passar pelo tapete e solta uma gargalhada enquanto diz: "Sou Will Smith e vou pegar meu Oscar" -, incorporam a figura de celebridades. Eles, pessoas comuns, subvertem o sentido do tapete vermelho. Naquela ocasião, desfilam com graça e desprendimento sobre o tapete enquanto são saudados com palmas e assobios pelos espectadores que estão no ponto de ônibus ou que passam pela rua.

Figura 13 - Intervenção "Pessoa muito importante" 


\section{Fonte: (INSTITUTO UNDIÓ)}

Aquele tapete tangiliza, ou quer tangibilizar, uma vivência, o que há de relacional na experiência estética, que é multidirecional. Eles próprios são os autores da performance, vivendo ali aspectos como a efemeridade e a dramaturgia da vida social em que os papéis e as funções são diferentes daquelas da vida real. "Olha, que surpresa ver este tapete aqui!” comenta Maristela, dona de casa. “... Ah, é arte? Interessante. Precisamos sempre nos renovar pra acompanhar o mundo. Eu acho!"”.

Aparentemente, o tapete, em forma de passarela, trouxe sensação de pertencimento por quem por ele passou. Será que transeuntes que nunca repararam na calçada passaram a se aperceber daquele espaço? E será que, naquela rápida interação, os transeuntes notaram as presenças uns dos outros como sujeitos e não meros passantes? De acordo com Cartaxo (2009), essas novas posturas e procedimentos não possuem o seu valor estético aderente à forma, mas uma condição de acontecimentoefêmero, em que a participação do público é relevante e, por vezes, imperceptível.

$\mathrm{Na}$ situação ritual, posto que a performance tanto é teatro quanto é ritual concepção da trança (Schechner, 2013) -, Agier nos recorda que as criações artísticas podem por em relação indivíduos diferentes, anônimos ou não, da multidão, "todos à procura de conexões e de associações que procuram existir contra o vazio de sentido e de relações que espreitam, como ameaça, qualquer habitante das cidades." (Agier, 2011: 174). No caso das pessoas que pisavam no tapete, elas expressavam o pertencimento e a visibilidade das diferenças ocupacionais e sociais no espaço urbano. 
A intervenção aciona, na performance participativa, a "arte desenmoldurada", que Canclini (2016) apresenta, discutindo a arte atual como sem rótulos, sem suporte fixo. São desmaterializadas (Zanini, 2018) e se fortalecem potencializando o que está implícito à poética proposta ao gerarem elucubrações e ao provocarem vivências singulares - posto que são experiências carregadas de subjetividade - e propõem discutir, entre outros temas, o ritmo urbano, com sua profusão de sistemas de signos.

"Eu acho os eventos que acontecem aqui ações úteis e necessárias!”. Assim, com essa frase de efeito, começamos nossa conversa, eu e a cabeleireira que, da janela, enxerga a casa do Undió. Ali na casa que ocupa com a filha há oito anos, funciona também o salão de beleza especializado em apliques: "é o mega hair", esclarece. "Conheci a Thereza de uma forma amistosa porque sempre que me via, me cumprimentava com um 'oi vizinha' e eu ficava feliz. É uma espécie de proximidade que não é apenas física, entende?”, relata. Quando eu me mudei, logo vi o movimento. Acho o momento de dividir a mesa ali na calçada valioso para rever a vizinhança", faz o comentário como um devaneio.

Figura 14 - Chuveiro (ducha) feito de latão, adaptado à árvore e, na foto, Thereza lava as mãos

Fonte: Foto da autora, 2019

Entusiasta das ações que testemunha da janela e que participa quando pode, ela acredita, pela sua fala, que muitas atrações são escolhidas para trazer afeto e identificação. É caso concreto o chuveiro (Figura 14), que ela recorda com alegria: 
[...] já vi e participei de tanta coisa bacana ali. Eu acho que a Thereza busca coisas que as pessoas conhecem, como a demonstração das plantas medicinais (ela se refere a uma mesa de chá que teve as ervas amarradas a uma corda sobre a mesa, em que as pessoas podiam fazer seu próprio chá), e o chuveiro feito de balde amarrado na árvore. Nossa... Nesse dia, eu fui lá pra minha terra e me senti criança outra vez: nós tomávamos muito banho de balde, eu e minhas três irmãs. Minha mãe enchia de água quente. O chuveiro achei muito interessante e tomei banho nele! Chegou a me emocionar mesmo. (Cabelereira).

\section{Considerações Finais}

O projeto Nessa rua tem um rio propõe uma arte "fora do campo" e se dispõe a estimular vivências afetivas para uma cidade sensível. Com interferências poéticas na Rua Padre Belchior e arredores, faz um convite para pequenas interrupções nos hábitos e ritmos usuais do centro da cidade, estimulando um olhar menos alheio num espaço urbano - o centro de uma grande cidade - onde múltiplos estímulos concorrem cotidianamente. Na prática, é como se por alguns instantes algo inusitado, fora do padrão e do esperado, ocorresse e impactasse o ritmo acelerado dos passos do pedestre. Um novo sentido de urgência se aciona pelo contato com as intervenções artísticas. $O$ caminhar apressado já automatizado cede lugar à pausa movida pelo estranhamento ou pela surpresa. $\mathrm{O}$ fato inédito pode ser uma mesa de café repleta de quitutes ou um filme sendo exibido na parede de uma casa.

A etnografia trouxe evidências sobre como os modos de percepção dos momentos de intervenção de arte diferem entre os interlocutores ouvidos. Os moradores e os comerciantes realçam aspectos da sociabilidade, ainda que não tratem os encontros causais por esse nome. Em sua maioria, destacam os momentos como agradáveis. Os transeuntes se surpreendem com um café sendo coado na hora ali na calçada ou com o tapete estendido na rua, mas junto com a curiosidade e a surpresa, ficam atentos à beleza plástica da mesa de café e à "bondade" da ação. Juntos, comerciantes, moradores e transeuntes, parecem não entender as atividades artísticas como arte, porém apreciam o que podem testemunhar ali. As intervenções são atividades sem capacidade de alterar a rotina, os usos e apropriações da rua pelos comerciantes, moradores e transeuntes, que percebem essas ações como um momento de diversão e lazer que não altera a sua rotina. 
Ainda que não saibam, são participantes da arte relacional e, na experiência que os torna fruidores, o questionamento, o desconforto e a ruptura fazem parte da construção de sentidos. A arte da performance, tão historicamente vinculada à rua, que surge como algo pleno de experimentalismo, uma reação às artes simplificadas e reduzidas ao entretenimento, tem a capacidade de transformar, gerar empatia, causar espanto e provocar efeitos lúdicos e/ou críticos em atores e espectadores. Na ocupação de espaços, é uma contraposição ao museu, suas regras de uso e de experiência medida. As performances são a forma mais recorrente de intervenções de arte na rua que este artigo estuda.

Dentre todas as ações que pude observar, o Café Comunitário recebe maior aderência dos transeuntes e dos comerciantes. Aciona para eles a hospitalidade, as referências do lar e as memórias familiares. No entanto, termina por ser um chamariz para outras intervenções artísticas que ocorrem simultaneamente naquele dia em que o Undió organiza uma temporada do projeto Nessa Rua Tem um Rio. Trata-se de manifestações artísticas que se esgotam no instante mesmo de seu acontecimento trazendo interpelações quanto à impermanência da arte. E ainda deixam sem resposta a questão de um eventual desdobramento, ou afetação, para aquelas pessoas que vivenciaram aqueles acontecimentos artísticos, sejam elas admiradoras ou não de arte.

Gestores, voluntários e artistas destacam essa fruição subjetiva que garante o choque de sentidos. Mesmo que não dêem atenção ao rótulo de "arte" para o que acontece no Nessa Rua Tem um Rio, garantem que em cada ação há arte e há resistência. Para os artistas, as ações artísticas do projeto Nessa Rua Tem um Rio têm o sentido de dar visibilidade e transformar os significados, resgatar memória, aguçar a sensibilidade e pôr em evidência uma antiga e pequena rua da capital mineira. As ações artísticas são estratégia de "reinventar" a percepção sobre o referido espaço e contribuir para atrair e possibilitar novos usos da rua e apropriação do lugar, em direção à cidade sensível.

Ao ocupar a rua, local de deslocamento de muitas pessoas que se movem ou se fixam com interesses diversos, há um convite aberto - informal e impreciso - a quem queira ou se interesse por parar, por olhar, por fazer parte e, em última análise, por se deixar afetar. Convite sutilmente aceito, a arte produzida pode, então, acessar a experiência de fruição, tão subjetiva. E se a experiência - que é vivência que requer presença -, é valorosa, o tempo despendido passa a ser uma variável fundamental: estar simultâneo à obra ou estar presente enquanto ela acontece. 


\section{REFERÊNCIAS}

AGIER, Michel. Antropologia da cidade: lugares, situações movimentos. São Paulo: Terceiro Nome, 2011.

ARANTES, Antônio Augusto. Guerra dos lugares: mapeando zonas de turbulência. In: ARANTES, Antônio Augusto. Paisagens paulistanas: transformações do espaço público. Campinas: Editora da UNICAMP, 2000. p. 105-130.

ARGAN, Giulio. Arte moderna. São Paulo: Companhia das Letras, 1992.

AVELLAR, Wilson. Eu rio. Nessa rua tem um rio, 30 out. 2010. Disponível em: $<$ https://nessaruatemumrio.wordpress.com/dia-a-dia/sabado-30-outubro2010/acaowilson-de-avellar/>. Acesso em: out. 2019.

BECKER, Howard S. Falando da sociedade: ensaios sobre as diferentes maneiras de representar o social. Rio de Janeiro: Jorge Zahar, 2009.

BELO HORIZONTE. Decreto $n^{\circ} 43$, de 7 de setembro de 1929. Dispõe sobre denominação de praça, conforme especifica. Diário Oficial do Município, Belo Horizonte, 8 set. 1929. Disponível em: $<$ https://eismunicipais.com.br/a/mg/b/belohorizonte/decreto/1929/4/43/decreto-n-431929-dispoe-sobre-denominacao-depraca-conforme-especifica-1929-09-07>. Acesso em: 18 fev. 2018.

BELO HORIZONTE. Prefeitura Municipal. Carnaval de Belo Horizonte cresce em 2019 e encanta 4,3 milhões de foliões. Belo Horizonte: PBH, 2019. Disponível em: $<$ https://prefeitura.pbh.gov.br/noticias/carnaval-de-belo-horizonte-cresce-em-2019eencanta-43-milhoes-de-folioes $>$. Acesso em: jan. 2020.

BISHOP, Claire. Antagonismo e estética relacional. Revista Tatuí, Recife, n. 12, p. 109132 ,

BORSAGLI, Alessandro. Rios de Belo Horizonte. In: SCOVINO, Felipe et al. (Org.). 
Escavar o futuro. Belo Horizonte: Piseagrama, 2014. p. 260-269.

BRASIL, André. Entre ver e não ver: o gesto do prestidigitador. In: GUIMARÃES, Cesar; LEAL, Bruno Sousa; MENDONÇA, Carlos Camargo (Org.). Comunicação e experiência estética. Belo Horizonte: Humanitas, 2006.

BURRO sem rabo. In: AULETE digital. <http://www.aulete.com.br/burro-sem-rabo>. Acesso em: 08 jan. 2020.

CAIAFA, Janice. Aventura nas cidades. Rio de Janeiro: FGV Editora, 2007.

CAMPBELL, Brígida. Arte para uma cidade sensível. São Paulo: Invisíveis Produções, 2015 .

CAMPBELL, Brígida. Arte para uma cidade sensível: arte como gatilho sensível para novos imaginários. São Paulo: B. Campbell, 2018.

CANCLINI, Néstor Garcia. A sociedade sem relato: antropologia e estética da iminência. São Paulo: Edusp, 2016.

CANEVACCI, Massimo. A cidade polifônica: um ensaio sobre a antropologia da comunicação urbana. São Paulo: Studio Nobel, 1997

CANTON, Katia. Do moderno ao contemporâneo. São Paulo: Martins Fontes, 2009.

CARTAXO, Zalinda. Arte nos espaços públicos: a cidade como realidade. O Percevejo Online, v.1, n. 1, p. 1-16, jan./jun. 2009. Disponível em: <http://www.seer. unirio.br/index.php/opercevejoonline/article/view/431/381>. Acesso em: jan. 2020.

CAUQUELIN, Anne. Arte contemporânea: uma introdução. São Paulo: Martins Fontes, 2005.

CLARK, Terry Nichols. Scenes contribute to the growth and decline of communities. MuniNetGuide, 2008. Disponível em: $<$ https://muninetguide.com/ scenes-contribute-tothe-growth-and-decline-of-communities/>. Acesso em: 10 set. 2019. 
COCCHIARALE, Fernando. A (outra) arte contemporânea brasileira: intervenções urbanas micropolíticas. Revista do Programa de Pós-Graduação em Artes Visuais EBAUFRJ. Rio de Janeiro, n. 11, p. 67-71, 2004.

CURRAL DEL REY. O vale do Córrego do Leitão entre os anos 1920 e 1930, nas proximidades da área central. 2010. Disponível em: <http://curraldelrei.blogspot. com/2010/08/o-vale-do-corrego-do-leitao-entre-os.html>. Acesso em: 10 set. 2019.

DAMATTA, Roberto. Carnavais, malandros e heróis: para uma sociologia do dilema brasileiro. 4. ed. Rio de Janeiro: Zahar, 1983.

DEBORD, Guy. A sociedade do espetáculo: comentários sobre a sociedade do espetáculo. Rio de Janeiro: Contraponto, 1997.

ECKERT, Cornelia; ROCHA, Ana Luiza Carvalho. Etnografia de rua: estudo de antropologia urbana. Iluminuras, v. 4, n. 7, p. 1-22, 2003. Disponível em: $<$ https://seer.ufrgs.br/iluminuras/article/view/9160/5258>. Acesso em: 29 jan. 2020.

FORTUNA, Carlos. A cidade como palco. Precisamos mais teatro! In: (FORTUNA, Carlos et al. Org.). Cidade e espetáculo: a cena teatral luso-brasileira contemporânea. São Paulo: EDUC, 2013. p. 17-22.

FOSTER, Hal. O retorno do real: a vanguarda do final do século XX. São Paulo: Cosac Naify, 2014.

FREITAS, Artur. Arte de guerrilha: vanguarda e conceitualismo no Brasil. São Paulo: Editora da Universidade de São Paulo, 2013.

GEERTZ, Clifford. A arte como um sistema cultural. In: GEERTZ, Clifford. O saber local. Petrópolis: Vozes, 1997. p. 142-181.

GEERTZ, Clifford. Uma descrição densa: por uma teoria interpretativa da cultura. In: GEERTZ, Clifford. A interpretação das culturas. Rio de Janeiro: Guanabara, 1989. p. $13-41$. 
GOFFMAN, Erving. A ordem da interacção. In: GOFFMAN, Erving. Os momentos e seus homens. Lisboa: Relógio d’Água, 1999.

GUIMARÃES, Cesar; LEAL, Bruno S.; MENDONÇA, Carlos C. (Org.). Comunicação e experiência estética. Belo Horizonte: Humanitas, 2006.

GUIMARÃES, Cesar. O que ainda podemos esperar da experiência estética? In: GUIMARÃES, César; LEAL, Bruno; MENDONÇA, Carlos. Experiência estética e comunicação: a partilha de um programa de pesquisa: entre o sensível e o comunicacional. Belo Horizonte: Autêntica: 2010.

GULLAR, Ferreira. Na vertigem do dia. Rio de Janeiro: Companhia das Letras, 2017.

HARVEY, David. Cidades rebeldes: do direito à cidade à revolução urbana. São Paulo: Martins Fontes, 2014.

INGOLD, Tim. Pare, olhe, escute! Visão, audição e movimento humanos. Ponto Urbe, São Paulo, Ano 2, n. 3, jul. 2008. Disponível em: <https://journals.open edition.org/pontourbe/1925>. Acesso em: 15 dez. 2019.

INSTITUTO ÚNDIO. Nessa rua tem um rio: sede Úndio (em 1966). 2012. Disponível em: $\quad<$ https://nessaruatemumrio.wordpress.com/2010/10/22/sede-undioem-1966/>. Acesso em: 15 dez. 2019.

JACOBS, Jane. Morte e vida nas grandes cidades. 3. ed. São Paulo: Martins Fontes, 2011.

JACQUES, Paola Berenstein (Org.). Apologia da deriva: escritos situacionistas sobre a cidade. Rio de Janeiro, Casa da Palavra, 2003.

JESUS, Eduardo de. Arte menor: mal entendidos e arte contemporânea, vida cotidiana e experiência estética. Trabalho apresentado no XXIII Encontro Anual da Compós, 2015, Florianópolis. Disponível em: <http://www.compos.org.br/biblioteca/ completo2015_2774.pdf>. Acesso em: 06 nov. 2015.

JESUS, Eduardo de. Relações entre arte e tecnologia: traços históricos e desdobramentos atuais. In: OLIVEIRA, Bruno; CUNHA, Maria Helena; RENA, 
Natasha (Org.). Arte e espaço: uma situação política do século XXI. Belo Horizonte: Duo Editorial, 2016. p. 158-173.

KATZ, Helena. É chegada a hora de enfrentar a subnutrição cultural. $O$ Estado de $S$. Paulo, 10 jan. 2003.

LEFEBVRE, Henri. O direito à cidade. São Paulo: Centauro, 2011.

LEITE, Rogerio Proença. Contrausos da cidade: lugares e espaço público na experiência urbana. Campinas: Editora Unicamp, 2004.

LUCIE-SMITH, Edward. Os movimentos artísticos a partir de 1945. São Paulo: Martins Fontes, 2006.

MAGNANI, José Guilherme C. De perto e de dentro: notas para uma etnografia urbana. Revista Brasileira de Ciências Sociais, v. 17, n. 49, p. 11-29, jun., 2002. Disponível em: $<$ http://www.scielo.br/pdf/rbcsoc/v17n49/a02v1749.pdf>. Acesso em: 06 nov. 2019.

MAGNANI, José Guilherme C. Quando o campo é a cidade. In: MAGNANI, José Guilherme C.; TORRES, Lílian de Lucca (Org.). Na metrópole. São Paulo: Edusp, 2000.

MENDONÇA, Carlos Camargos. Ao homem em ruínas restaram as imagens? In. GUIMARÃES, César; LEAL, Bruno Souza; MENDONÇA, Carlos Camargos (Org.). Comunicação e experiência estética. Belo Horizonte: Ed. UFMG, 2006. p. 103-113.

MENDONÇA, Carlos Magno Camargos; MORICEAU, Jean-Luc; PAES, Isabela.

Guerrilhas do sensivel: estetização e contra-estetização do mundo. Compós, 2015.

Disponível em: <http:/www.compos.org.br/biblioteca/guerrilhasdosensi-velcompos 2015_2772.pdf>. Acesso em: 11 nov. 2015.

MORAES, Antônio Carlos Robert. Flávio de Carvalho: o performático precoce. São Paulo: Brasiliense, 1986.

O'DOHERTY, Brian. No interior do cubo branco: a ideologia do espaço da arte. São Paulo: Martins Fontes, 2007. 
OLIVEIRA, Roberto Cardoso de. Ensaios sobre moral e ética. Rio de Janeiro: Tempo Brasileiro, 1996.

PALLAMIN, Vera Maria. Arte urbana: São Paulo: Região central (1945-1998): obras de caráter temporário e permanente. São Paulo: Annablume, 2000.

PEIRANO, Mariza. Etnografia, ou a teoria vivida. Ponto Urbe, n. 2, 2008. Disponível em: <https://journals.openedition.org/pontourbe/1890> Acesso em: 06 nov. 2019.

PEIRANO, Mariza. Rituais como estratégia analítica e abordagem antropológica. In: PEIRANO, Mariza (Org.). O dito e o feito: ensaios de antropologia dos rituais. Rio de Janeiro: Relume Darumá, 2002a. p. 7-14.

PORTES, Thereza. Impactos de ações de mediação cultural: nessa rua tem um rio. In: LIBÂNIO, Clarice de Assis (Org.). Arte, cultura e transformação social: caderno de experiências. Belo Horizonte: Favela é isso aí, 2015. p. 48-51.

RANCIÈRE, Jacques. A partilha do sensivel: estética e política. São Paulo: Ed. 34, 2005.

RIO, João do. A alma encantadora das ruas. São Paulo: Companhia das Letras, 2008.

ROCHA, Ana Luiza Carvalho da; ECKERT, Cornelia. Etnografia da duração: antropologia das memórias coletivas nas coleções etnográficas. Porto Alegre: Marcavisual, 2013.

SCHECHNER, Richard. "Pontos de contato" revisitados. In: DAWSEY, John C. (Org.) Antropologia e performance: ensaios napedra. São Paulo: Terceiro Nome, 2013. p. 3765.

STOTT, Tim. Uma entrevista com Grant H. Kester. Revista Poièsis, Niterói, n. 23, p. 75-84, jul. 2014. Disponível em: <http://www.poiesis.uff.br/p23/p23pdf/p23entrevista.pdf $>$. Acesso em: 06 nov. 2019.

TARDE, Gabriel. A opinião e as massas. São Paulo: Martins Fontes, 1992. 
TAYLOR, Diana. Traduzindo performance Kester. In: DAWSEY, John C. (Org.). Antropologia e performance: ensaios napedra. São Paulo: Terceiro Nome, 2013. p. 917.

VELHO, Gilberto. O desafio da proximidade. In: VELHO, Gilberto; KUSCHNIR, Karina (Org.). Pesquisas urbanas: desafios do trabalho antropológico. Rio de Janeiro, Zahar, 2003.

VOGEL, Arno; MELLO, Marco Antônio da Silva. Quando a rua vira casa. 4. ed. Niterói: Editora da Universidade Federal Fluminense, 2017.

VOILAT, Georges. En remontant la rue Vilin 1992. Um filme de Robert Bober. YouTube, 2016. Disponível em: <https://www.youtube.com/watch?v=8HfvFHQ-j6s $>$. Acesso em: 06 nov. 2019.

ZANINI, Walter. Vanguardas, desmaterialização, tecnologias na arte. São Paulo: Martins Fontes, 2018.

Recebido: 30/06/2020

Aprovado: 04/09/2020 